\title{
DESPÓTIKO: ESCAVAÇÕES E RESTAURAÇÃO DE UM SANTUÁRIO DE APOLO ${ }^{12}$
}

\author{
Excavation and Restoration of the Sanctuary of Apollo
}

\author{
Yannos Kourayos ${ }^{3}$ \\ Kornilia Daifa ${ }^{4}$
}

\begin{abstract}
RESUMO
As escavações em Despótiko (considerado pelas autoridades arqueológicas gregas uma das descobertas mais importantes da última década) trouxeram à luz um vasto santuário de Apolo jamais mencionado por fontes literárias (Despótiko é o segundo maior santuário de Apolo nas Cíclades e, no início do Período Arcaico, chegou a ser maior do que o de Delos). Os edifícios e materiais descobertos estão impactando o entendimento sobre as atividades religiosas na Cíclades e na região mediterrânica em questão. Este breve artigo pretende fazer uma apresentação geral do santuário de Apolo em Despótiko destacando alguns dos edifícios votivos encontrados no sítio. $O$ presente texto também introduz brevemente o projeto de restauração do principal edifício de culto do santuário.
\end{abstract}

Palavras-chave: Apolo; Santuários Cicládicos; Paros; Despótiko.

\begin{abstract}
The excavations at Despotiko (considered by Greek archaeological authorities as one of the most important discoveries of the last decade) have brought to light a vast sanctuary of Apollo that is mentioned in no surviving literary source. The sanctuary of Apollo at Despotiko is the second largest sanctuary dedicated to this god in the Cyclades, and one
\end{abstract}

1 Texto com a tradução de Erica Angliker, Research Fellow at Institute of Classical Studies, School of Advanced Study (University of London) e Lorena Lopes da Costa, Associate Professor at Federal University of Western Pará.

2 Gostaríamos de agradecer a Alexandra Alexandridou (membro da equipe científica de Despótiko) por ter compartilhado conosco avaliações e estudos em andamento (muitos ainda não publicados) sobre Despótiko. Também agradecemos a Erica Angliker (membro científico das escavações em Despótiko) pela revisão geral dos dados arqueológicos deste texto e pela organização das fotos e mapas. A ela novamente e também a Lorena Lopes da Costa, agradecemos ainda a tradução para o português.

3 Minister of Culture and Sports, director at the excavations on Despotiko. E-mail: kourayos@hotmail.com 4 Member of the excavations at Despotiko. E-mail: kodaifa@yahoo.gr 
that early in the Archaic Period, was even greater than that of Delos. The buildings and materials discovered are impacting our understanding of religious activities in the Cyclades and the Mediterranean region around them. This brief article offers a general presentation of the sanctuary of Apollo in Despotiko while highlighting some of the votive buildings at the site. It also briefly introduces the restoration project for the chief cult structure at the sanctuary.

Keywords: Apollo; Cycladic Sanctuaries; Paros; Despotiko.

\section{Introdução}

A ilha desabitada de Despótiko fica a apenas 700m de Antiparos, em uma posição estratégica no centro das Cíclades, possuindo pequena extensão (apenas 7,65 km²) (figura 1) (KORAYOS, 2012). Com Siphnos a leste e Paros e Antiparos a oeste, Despótiko fica entre as ilhotas de Strongylo (a oeste) e Tsimintiri (a leste). A ilha é caracterizada por clima seco, terreno rochoso e montanhas altas no interior. Ao norte, sua costa é íngreme e, sempre varrida pelo vento, não permite acesso. $O$ único ponto acessível nessa parte da ilha é a baía de Livadi. A costa oriental confronta Antiparos; juntas, as duas ilhas formam também uma espécie de baía que serve como porto natural protegido (Estrabão, 10.5.3; Plínio, 4.66). Fotos de satélite e observações geológicas revelam, aliás, que, antes do aumento do nível do mar, essa reentrância natural estava fechada no extremo norte, quando Tsimintiri se juntava a Despótiko (figura 2) (KOURAYOS, 2005; 2006b; 2018; no prelo).

Até agora, não foi encontrado nenhum documento epigráfico que mencione o santuário de Despótiko, tampouco o enorme santuário de Apolo da ilha foi citado por algum escritor da antiguidade. A ilha, porém, é mencionada duas vezes por geógrafos antigos. Em seus catálogos, Plínio e Estrabão se referem a Prepesinthos, nome que foi associado a Despótiko, embora não esteja claro se esse nome foi usado pelos devotos de Apolo que visitaram o santuário. Depois do abandono completo da ilha no Período Romano, Despótiko foi habitada apenas esporadicamente por grupos diminutos, e os últimos habitantes moraram na ilha nos séculos XVI e XVII (figura 3). De fato, mapas desse período trazem a representação da ilha, a qual nomearam Sigilo, com um pequeno castelo. Hoje, enfim, Despótiko é uma ilha de pastagem de cabras usada para microtransumância. 
O silêncio dos antigos e o longo abandono do local não sugerem, então, que a ilha tenha abrigado um santuário muito ativo de Apolo. Os antigos também nada dizem sobre as ilhotas em torno de Despótiko (Tsimintiri e Strongylo), igualmente desabitadas nos dias de hoje. Embora nenhuma dessas ilhas possua um santuário grandioso como o de Despótiko, elas testemunharam atividades humanas no passado na Idade do Bronze. Pesquisas realizadas em Tsimintiri descobriram fragmentos de cerâmica que variam desde a era Pré-Histórica até o Período Helenístico. Foram ainda descobertos vestígios de três grandes edifícios, ainda não totalmente estudados (KOURAYOS, BURNS, 2005). Sabemos que Tsimintiri foi usada como local de sepultamento, o que explica o significado de "Koimitiri" (uma variação no nome de Tsimintri), local de repouso. A cerâmica de períodos variados também foi encontrada em Strongylo, aqui existindo ruínas de uma pequena igreja pós-bizantina construída parcialmente com espólio, como é o caso das duas colunas monolíticas não vazadas de mármore de Paros, provavelmente provenientes de algum edifício helênico (KOURAYOS, 2005; 2006b; 2006b; 2018; no prelo; KOURAYOS, DOHNESORG, PAPAJANNI, 2012).

Por séculos, as construções antigas de Despótiko permaneceram esquecidas por estudiosos da cultura grega antiga. Após o sítio ter sido definitivamente abandonado no Período Romano, as antiguidades da ilha não foram aludidas em nenhum tipo de escrito. Despótiko passou a ser objeto de atenção somente no final do século XIX, quando o viajante inglês Theodore Bent visitou o campo de Mandra na ilha e mencionou ter encontrado construções ancestrais. Bent, que registrou as escavações que conduziu na ilha por um curto período, relata a descoberta de um templo. Seus trabalhos em Despótiko se inseriam numa vigorosa busca por necrotérios da antiguidade nas Cíclades, semelhantes aos que escavara ilegalmente em Antiparos (BENT, 1885, p. 199-206).

Uma vez que Bent era um viajante interessado mas não um arqueólogo profissional, as primeiras investigações arqueológicas científicas de fato sobre Despótiko ocorreram no final do século XIX pelo renomado pesquisador Christos Tsountas, que escavou dois cemitérios da Idade do Bronze das Cíclades (terceiro milênio a. C.) na parte sul da ilha, nos locais de Zoumbaria e Livadi , bem como parte de um assentamento das Cíclades no local de Cheiromylos (Tsountas,1898) (figura 4). Na sequência, mas apenas em 1959, N. Zapheiropoulos realizou em Zoumbaria uma escavação de resgate a fim de evitar atos de pilhagem. Ele revelou, então, mais vinte túmulos das Cíclades Primitivas. Muitos anos depois, em 2001, descobrimos 
parte de outro assentamento datado do início da Idade do Bronze na mesma área. Tal assentamento fornece importantes evidências para o entendimento dos primeiros habitantes da ilha de Despótiko (KOURAYOS, 2005; 2006a; 2006b; 2018; no prelo).

Em 1985, os arquitetos alemães G. Gruben, M. Schuller e A. Ohnesorg da Escola Politécnica de Munique visitaram Mandra em busca de vestígios das construções antigas e descobriram que as estruturas identificadas por Zapheiropoulos, em 1959, haviam sido cobertas pela terra; vários de seus elementos tendo sido usados num abrigo de cabras. Apesar disso, Schuller realizou um estudo sobre os restos arqueitetônicos e propôs a reconstrução de um dos edifícios. Observando que tais vestígios tinham dimensões complementares, propôs que pertencessem à mesma estrutura. O edifício teria sido construído até o final do Período Arcaico, haja vista as bases do perfil dos capitais. Vendo que se tratava da ordem dórica, Schuller localizou a estrutura estilisticamente entre o Héraion de Delos e o templo de Ártemis em Paros (ambos anteriores a 500 a. C.). Ele também observou que a construção tinha peculiaridades de outros edifícios dóricos da região, como a ausência de guta nos mísseis (como no templo de Ártemis em Paros) e o uso de colunas não caneladas com as capitais dóricas (como em Paros e Delos).

Independentemente desses esforços iniciais, a ilha de Despótiko permaneceu inexplorada por um longo tempo (SCHULER, 1985). O trabalho arqueológico foi retomado apenas em 1997, por nossa equipe (sob direção de Yannos Kourayos), que conduziu, primeiramente, uma escavação de resgate. Após uma rápida pesquisa de superfície, no decurso da qual detectou-se pedras antigas de mármore espalhadas dentro e ao redor do estábulo de cabras, as escavações sistemáticas do local foram iniciadas e, finalmente, revelararam um extenso estabelecimento e um grande centro de culto arcaico (KOURAYOS, 2005; 2006b; 2018; ANGLIKER, 2017; KOURAYOS, ANGLIKER et al, 2018).

Desde o ano 2000, conduzimos escavações sistemáticas no sítio de Mandra em trabalhos que contam com a participação de voluntários de diversos países (KOURAYOS, 2005; 2006b; 2018; KOURAYOS, ANGLIKER et al, 2018). ${ }^{5}$ Vinte anos de pesquisa têm trazido à luz um

5 Graças aos esforços da arqueóloga Erica Angliker e da Profa. Maria Cecília Coelho (UFMG) (coordenadoras do projeto Tocando o Passado) voluntários da UFMG, da UFPR e de outras universidades brasileiras têm participado regularmente das escavações de Despótiko desde 2016. 
extenso santuário arcaico com 22 edifícios e inúmeras revelações (figura 5). Com efeito, a descoberta do santuário mudou seriamente o cenário do sagrado das Cíclades, pois nada se sabia sobre sua existência ou seus fundadores; seu tamanho e sua riqueza estando ausentes de outros santuários arcaicos das ilhas, com exceção de Delos. Dentre os achados, destacam-se cerâmicas grafitadas com o nome de Apolo (figura 6), certamente o principal deus do santuário, ao menos durante os séculos VI e V a. C. Estatuetas femininas, joias, acessórios de toilette, uma cabeça de kóre e partes do torso de uma colossal estátua feminina indicam que uma deusa feminina também era adorada, provavelmente a irmã gêmea de Apolo, Ártemis. No Período Clássico tardio, tal como mostra a inscrição feita num altar, Héstia, com o epíteto Isthimia, também foi venerada (KOURAYOS, SUTTON, DAIFA, 2018; KOURAYOS, DIFA no prelo) (figura 7).

Embora o apogeu do desenvolvimento do santuário de Apolo tenha sido no século VI a. C., quando o temenos do santuário foi construído, já desde os primeiros anos da escavação fica evidente que a atividade no local precedeu a formação do temenos arcaico. Ora, dentro do templo arcaico, uma grande coleção de artefatos foi revelada, alguns datando do século VIII a. C. Também foram encontrados vestígios similares ao que se encontram em outras áreas concernentes à cerâmica do século VIII e início do século VII a. C. Nesse sentido, a evidência mais nítida das primeiras atividades no local vem da área do temenos, onde, logo abaixo do edifício arcaico $\Delta$, parte de um edifício apsidal foi escavada (edifício O). Deve-se salientar que edifícios ápsides são raros, este sendo um dos poucos descobertos nas Cíclades; outros dois em Páros (figura 8).

A cerâmica mais antiga encontrada no edifício $O$ data do final do século IX a. C., enquanto a mais recente, encontrada na camada que cobria sua estrutura, data do início do século VII a. C. As peças mais recentes fornecem uma indicação do período de uso. Apenas a alguns metros ao sul, em frente ao edifício, o estilóbato do templo foi descoberto (KOURAYOS, DAIFA, 2017). Com um plano retangular, ele data do final do século VIII/início do século VII a. C. Ao norte dessas estruturas, e logo abaixo do edifício $\Delta$, foi escavada ainda uma espessa camada de solo preto, contendo numerosos ossos de animais, como porcos, pássaros e ovelhas, além de cerâmica bastante decorada do Período Geométrico ao Período Arcaico. Tal camada continha grandes quantidades de vasos de forma aberta, com predominância de utensílios típicos do período Geométrico Tardio de Paros, conforme observado por A. Alexandridou. Não obstante não se tenha ainda certeza da 
função da estrutura, o conjunto do material indica atividades marcantes tanto de sacrifício quanto de banquete. Em relação a outras estruturas relacionadas às fases Geométrica e Arcaica iniciais do local, a construção semicircular que mais tarde serviu como altar do temenos arcaico foi erguida em algum momento no final dos séculos VIII e VII a. C., sendo, desde então, foco das atividades de culto (ALEXANDRIDOU, 2019; ALEXANDRIDOU, no prelo; ALEXANDRIDOU, DAIFA, no prelo).

Pouco antes da metade do século $\mathrm{V}$ a. C., o sítio foi arquitetonicamente transformado. Um temenos sagrado foi construído progressivamente acima das estruturas anteriores. Desse modo, o coração do santuário foi delimitado por um períbolo de aproximadamente 2.250 metros quadrados e três portas (norte, sul e leste). O temenos incluía o templo, o estiatório, o altar semicircular e o edifício $\Delta$ (que também estava relacionado às atividades de culto). Dos lados norte, sul e leste dos períbolos foram encontradas várias stoai (KOURAYOS, ALEXANDRIDOU, PAPAJANNI, DRAGANATIS, 2017). O edifício $E$ foi encontrado do lado de fora, mas quase em contato com os períolos sagrados. No passado, possivelmente existiam mais estruturas dentro dos temenoi, mas distúrbios no local na Antiguidade Tardia e nos tempos modernos podem ter causado sua destruição.

A evidência arqueológica e a arquitetura dos edifícios indicam que os temenoi assumiram sua forma final, gradualmente, entre os anos 550 a. C. e 500-490 a. C. A preservação de muitos membros arquitetônicos das colunatas - todos esculpidos em mármore de Paros — permitiu a restauração das fachadas do templo e o estiatório. O último foi restaurado com oito colunas dóricas não caneladas em antis, com três metros de altura, enquanto a fachada do templo pôde ser restaurada com sete colunas não caneladas em antis, com quatro metros de altura, apresentando uma arquitrave e um friso com tríglifos e métopas, coroados por uma cornija (figura 9). O templo tinha um telhado de duas águas com acrotérios de mármore em forma de palmeiras (KOURAYOS, OHNESORG, PAPAJANNI, 2012; KOURAYOS, DAIFA et al., 2020) (figura 10).

Além dos edifícios relacionados ao temenos, dois grandes complexos de edifícios (13 edifícios e uma torre, todos datando dos séculos VI e V a. C.) foram escavados. A alguns metros ao sul do temenos existiam as instalações auxiliares do santuário, atendendo às necessidades do sacerdócio e dos visitantes. As escavações em andamento revelaram ainda os edifícios $\Pi, \mathrm{M}$, $\mathrm{N}$; uma cisterna; o Complexo Leste com doze quartos e o Complexo Sul. Este último incluía um loutron usado para a purificação simbólica dos adoradores 
antes de sua entrada no temenos (figura 11). As necessidades diárias de água no santuário eram atendidas por dois poços profundos medindo dois metros e meio de diâmetro. Um deles foi descoberto dentro dos períbolos do Complexo Sul e o segundo do lado de fora, mas nas imediações do temenos. A leste dos temenoi havia mais dez prédios e uma torre (B, $\Gamma, \mathrm{Z}, \mathrm{H}, \mathrm{K}, \Lambda, \mathrm{P}$, $\Sigma, \mathrm{T}, \mathrm{Y})$. Esses edifícios cobrem uma extensa faixa de terra, desde a costa até o platô do santuário ao longo de toda a rota que os visitantes seguiriam do porto até os temenoi (KOURAYOS, OHNESORG, PAPAJANNI, 2012; KOURAYOS, ANGLIKER et al, 2018).

Cabe notar que várias estruturas, a saber, os edifícios e uma torre, foram igualmente encontrados na ilhota Tsimintiri, vizinha de Despótiko. Localizada a leste de Despótiko, Tsimintiri se conectava com aquela por um estreito istmo antes da elevação do nível do mar a que se referiu anteriormente. Seus edifícios devem, portanto, ser incluídos na área maior do santuário de Despótiko. Até o momento, ademais, seis estruturas retangulares foram escavadas na ilhota, e as escavações encontraram uma estrutura circular particularmente notável com 15 metros de diâmetro. Talvez utilizada para danças, a estrutura ainda precisa ser analisada para que seja possível definir com certeza sua função (figuras 12, 13 e 14). Vale notar, a propósito, que os edifícios de Tsimintiri foram investigados somente superficialmente e uma escavação intensiva resta a ser feita.

Por outro lado, em Despótiko, outros edifícios foram intensamente analisados. As descobertas do templo principal (edifício A) e de outros edifícios de culto, quais sejam, vasos, estatuetas, joias, pedras de foca, ferramentas, armas, kouroi arcaicos de mármore, indicam a riqueza do santuário (OHNESORG, 2017) (figuras 15 e 16 ). No edifício A também foi encontrado um raro selo arcaico com cena de dança (ANGLIKER, 2019 e 2020) (KOURAYOS, BURNS 2017; KOURAYOS, SUTTON HASSAKI, no prelo) (figura 17).

Com base no estudo do material arqueológico de Despótiko, do alfabeto utilizado nas cerâmicas com nome de Apolo e de outras escritas dedicatórias do santuário, concluiu-se que o santuário de Despótiko foi estabelecido e protegido pela polis de Paros. Essa polis sofreu uma obra ambiciosa na segunda metade do século VI a. C.: o estabelecimento de um santuário extra-urbano, que permaneceria sob sua proteção e influência, e poderia atrair visitantes de diferentes partes da Grécia para efetuarem atividades comerciais, trocas, circulação de produtos. 
O santuário em Despótiko seria um caso incomum de um santuário extra-urbano, que segundo o modelo de François de Polignac (1995), pode ter funcionado como uma demarcação simbólica do território de Paros e de sua extensa esfera de influência. O objetivo seria o de demonstrar o desejo de Paros de expandir seu território de culto, fortalecer uma identidade religiosa comum em uma esfera geográfica mais ampla e se envolver em um quadro complexo de competição e interação orientadas pela religião. No período, afinal, os habitantes de Paros desejavam consolidar sua presença nas Cíclades centrais, possivelmente devido à rivalidade com os vizinhos de Naxos e ao crescente domínio dos atenienses nas ilhas, incluindo Delos (KOURAYOS, SUTTON, DAIFA, 2018). Talvez a construção simultânea de templos e a reorganização de cultos em sua terra natal também servissem a essa ambição. De fato, Paros possuía inúmeros santuários. Os nomes de quase todos os deuses olímpicos são atestados ali, e achados arqueológicos testemunham que um programa ativo de construção religiosa ocorreu na ilha nos séculos VI e V a. C., que incluía o estabelecimento ou reorganização de locais de culto, não só na cidade, mas em áreas periféricas (KOURAYOS, DAIFA, 2017). Se, por um lado, a construção de templos e altares majestosos, monumentos votivos, juntamente com as esculturas, devem ter apresentado uma enorme carga de trabalho para os habitantes de Paros, por outro, essas obras testemunham a riqueza da ilha. Não deve ser coincidência, por isso, que Paros tenha mais santuários arcaicos e clássicos do que qualquer outra polis das Cíclades.

\section{Panteão}

Como mostraram os estudos iniciais de A. Alexandridou sobre o edifício $\Delta$, no Período Deométrico, uma divindade (provavelmente feminina) foi venerada em Despótiko num culto ligado à fertilidade. No Período Arcaico, contudo, Apolo se tornou o principal deus venerado no santuário. Seu culto é atestado por fragmentos de cerâmica com o nome do deus inscrito (KOURAYOS, 2006). Os inúmeros fragmentos dos kouroi encontrados no santuário também podem ter sido dedicados a ele (figuras 18, 19, 20, 21 e 22). Em Despótiko, como já mencionamos, inscrições atestam ainda o 
culto de Héstia sob o epíteto de Isthimia. É possível, por fim, que também Ártemis tenha sido venerada na ilha (KOURAYOS, OHNESORG, DIAFA PAPAJANNI, 2012; KOURAYOS, ANGLIKER et al, 2018). Brevemente, a adoração dos deuses em Despótiko deve ser entendida conforme o panteão de Paros, uma vez que o santuário pertencia à ilha.

\section{A Estátua de culto}

O depósito da sala A1 do principal edifício de culto do santuário inclui uma estátua feminina de terracota, que funcionou como estátua de culto do santuário (figura 68). A figura está preservada apenas da cintura para cima (altura de 25 centímetros) (figuras 23 e 24). Na parte esquerda, o antebraço e todo o braço direito são preservados (KOURAYOS, ANGLIKER, no prelo). ${ }^{6}$ A estátua está vestida com uma roupa cuja estampa com padrão de losango sugere um tecido bordado. A figura em terracota tem uma cabeça de estilo dedálico muito distinta, plana no topo com um rosto mais largo nas têmporas do que no queixo. Este triângulo facial é delimitado em ambos os lados por cunhas de cabelo em posição inversa que terminam pouco abaixo dos ombros. Seis cachos em espiral emolduram sua testa, e uma coroa de polos repousa sobre sua cabeça. Embora a coroa sinalize se tratar de uma divindade, a ausência de qualquer iconografia específica dificulta a identificação da estátua como uma deusa em particular.

Cotejando a estátua de terracota com figuras do mesmo estilo, é possível propor uma data de cerca de 650 a. C. (KOURAYIOS, BURNS, 2005). Não obstante a parte inferior do corpo estar ausente, pode-se reconstruí-la a partir da comparação com outras duas estatuetas de terracota de Siphnos muito semelhantes à de Despótiko. Naquelas, a parte inferior dos corpos assume uma forma cilíndrica. Reconstruída, a estátua mede 65 centímetros de altura. As análises estilísticas de sua cerâmica sugerem se tratar de um produto de Paros que imita as esculturas dedalianas em cerâmica (KOURAYOS, 2018).

6 Uma outra interpretação foi apresentada por Alexandridou, 2018. 
Durante o desenvolvimento das escavações, outra estatueta de argila apareceu na sala A1, parecendo ser única. Essa estatueta, igualmente do século VII a. C., está mal preservada. Seu corpo é também cilíndrico, trabalhado em vermelho e preto, decorado com linhas horizontais pintadas, entre as quais há escamas. O padrão lembra tecidos luxuosos adornados com placas de metal. Se a cabeça está muito danificada, no pescoço está pintado o que parece ser um colar duplo com um pingente redondo do qual pende um objeto em forma de cruz. A cabeça, porém, mesmo estando danificada, é uma peça que revela o interessante processo de fabricação da peça, pois é separada do corpo, encaixando-se nele. Finalmente, em 2013, parte de outra grande estatueta de argila veio à tona no nível das fundações da pré-construção do Edifício D. Somente parte do torso inferior está preservada, decorada com tinta vermelha, preta e branca, em um padrão que parece representar tecidos luxuosos.

A presença dessas estatuetas no santuário indica que elas não poderiam todas funcionar como o ídolo do culto do santuário. Fenômeno semelhante ocorre em Siphnos, onde duas grandes estátuas de barro, datando do mesmo período que as encontrados em Despótiko, foram descobertas entre os depósitos votivos. Embora alguns estudiosos tenham classificado os ídolos de Siphnos como as estátuas de culto do santuário, seríamos mais cautelosos ao fazer tal afirmação (ANGLIKER, 2014). De fato, uma leitura cuidadosa dos relatórios arqueológicos revela que as duas estátuas de argila de Siphnos foram acompanhadas por outras estátuas de argila de tamanho e material semelhantes. Braços e até uma cabeça que não combinam com as duas estátuas revelam que o número de estátuas de argila em Siphnos, certamente, consistia em mais de dois itens. ${ }^{7}$ No caso de Despótiko, no entanto, pode haver uma distinção entre as três estatuetas. Apenas a de estilo dedálico é significativamente maior que as outras duas e a arte empregada nela, para além de seu significado, revela o gasto em sua fabricação. Essas características nos levam a ver a imagem como ídolo do culto, devido a seu tamanho incomum, para uma estátua de terracota, e à posição de seus braços (KOURAYOS, BURNS, 2005). Também sustentamos que a estatueta de argila pode ter sido substituída por outra estátua de culto por volta de 500490 a. C. Das três grandes bases descobertas no edifício A, há características

7 Para um panorama dos cultos em Siphnos ver: Angliker, 2014. 
que mostram claramente que uma estátua foi anexada a ela. Mais importante, a base é comparável à de uma estátua de culto de Ártemis encontrada no Delion em Paros (500-490 a. C.). Ademais, as características do torso de uma estátua feminina, encontrado num curral em 2002, nos permite conectá-lo à base mencionada. $\mathrm{O}$ torso mostra, claramente, uma mulher curvada com a perna para a frente e, embora menor, se assemelha à colossal estátua de culto de Ártemis, de Delion em Paros (KOURAYOS, 2017).

\section{Restauração}

Despótiko foi, recentemente, declarado patrimônio culturalarqueológico. Com isso, nenhuma construção é permitida no local. O objetivo principal do Projeto Despótiko é, com efeito, a proteção e aprimoramento dos monumentos e do sítio arqueológico como um todo. O templo e o Estiatório do santuário não são apenas únicos em termos de layout e construção arquitetônicos, mas também em termos de função, pois constituem o único caso atualmente conhecido nas Cíclades em que um Estiatório Arcaico fica ao lado de um templo Arcaico. Assim, desde que as escavações e a documentação arquitetônica completa foram concluídas, o projeto de restauração foi iniciado em 2014, permitindo o aprimoramento dessas estruturas.

O estudo de restauração foi precedido pela gravação de todos os elementos que integravam a arquitetura no local (figuras 25-31). Cada um desses elementos foi gravado em 3D em qualidade fotorrealista e alta precisão por meio de fotogrametria. A restauração proposta, indicada pela reconstrução teórica, tem como requisito incorporar a quantidade máxima possível de material antigo, mantendo-se em proporção de cerca de $40 \% \mathrm{com}$ relação ao material novo. Os trabalhos de estudo e restauração aprovados incluem ainda a restauração do estilóbato dos dois edifícios, de partes de suas colunatas, bem como a restauração de suas paredes. Uma quantidade considerável de elementos arquitetônicos antigos que sobreviveram ao tempo, considerados suficientemente preservados e capazes de serem integrados a novos materiais, será usada dessa mesma forma (KOURAYOS, DAIFA et al, 2020) . 
O projeto de restauração busca benefícios técnicos, educacionais e estéticos. Após a conclusão do projeto de restauração, um único monumento arcaico das Cíclades será acessível a todos os visitantes. O resultado almeja ser instrutivo e educacional, não apenas para estudiosos, portanto, mas também para o público em geral. Nosso objetivo é criar em Despótiko um parque arqueológico protegido que reacenda o interesse pela cultura das antigas Cíclades.

\section{Lista de Figuras}

\section{Figura 1 - Mapa das ilhas cicládicas mostrando a localização do santuário de Despótiko.}

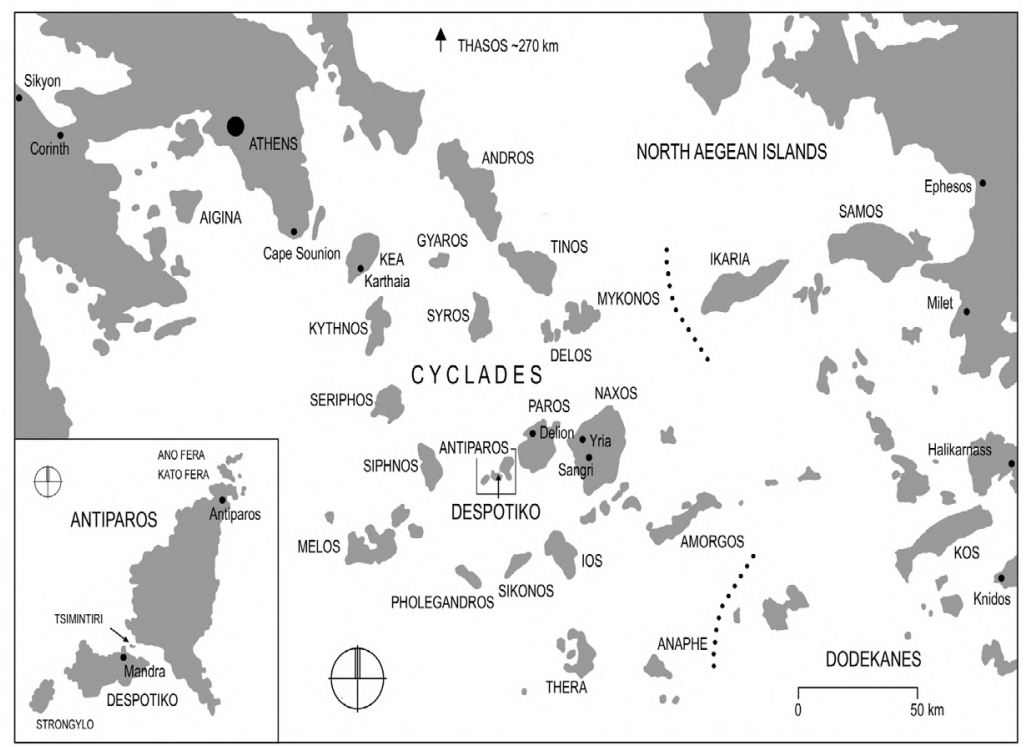


Figura 2 - Foto aérea de Despótiko e Tsimintiri mostrando que as duas ilhas estiveram ligadas, formando um istmo antes da elevação do nível do mar.

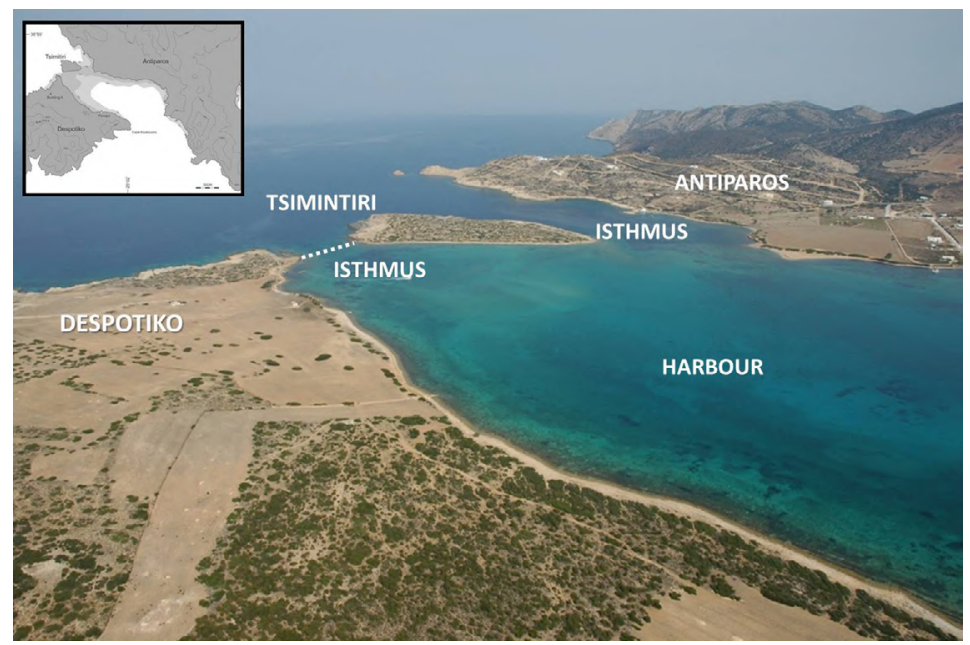

Figura 3 - Mapa de Olfert Dapper (1688) mostrando um castelo na ilha de Despotiko.

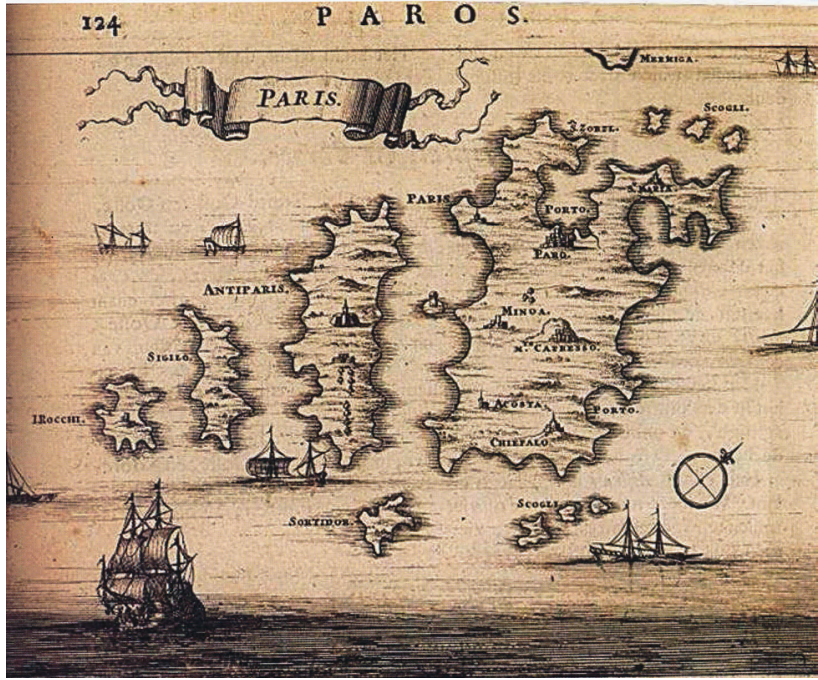


Figura 4 - Zoumbaria, onde foram encontradas as tumbas da idade do Bronze.

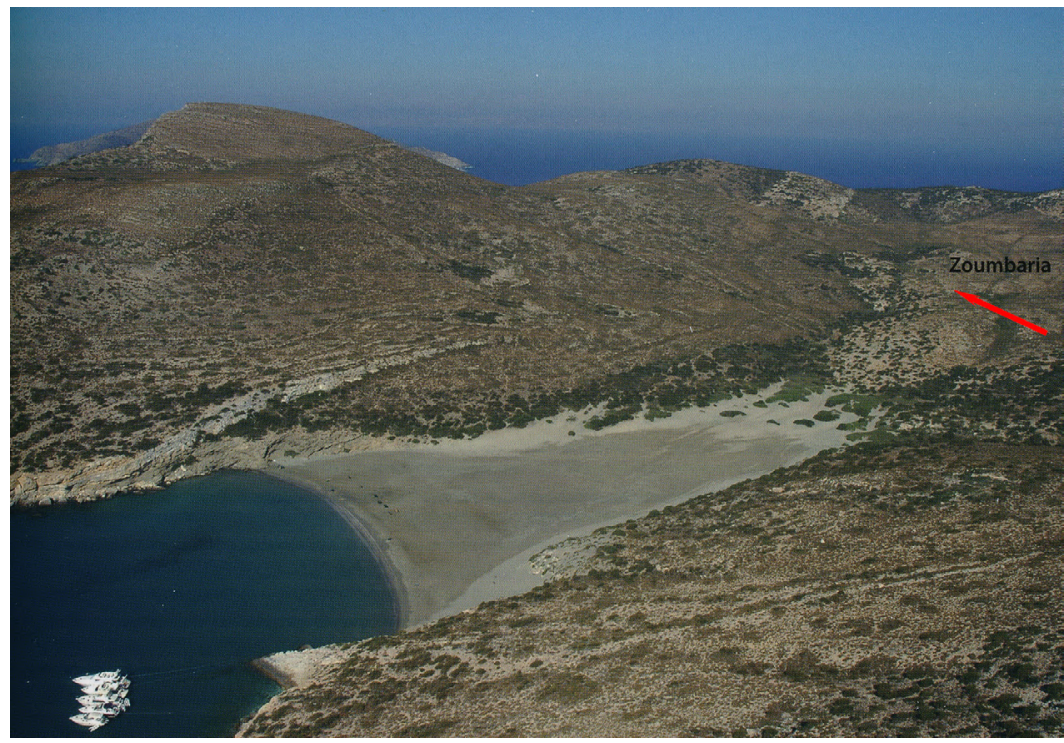

Figura 5 - Vista aérea do santuário de Apolo em Despótiko.

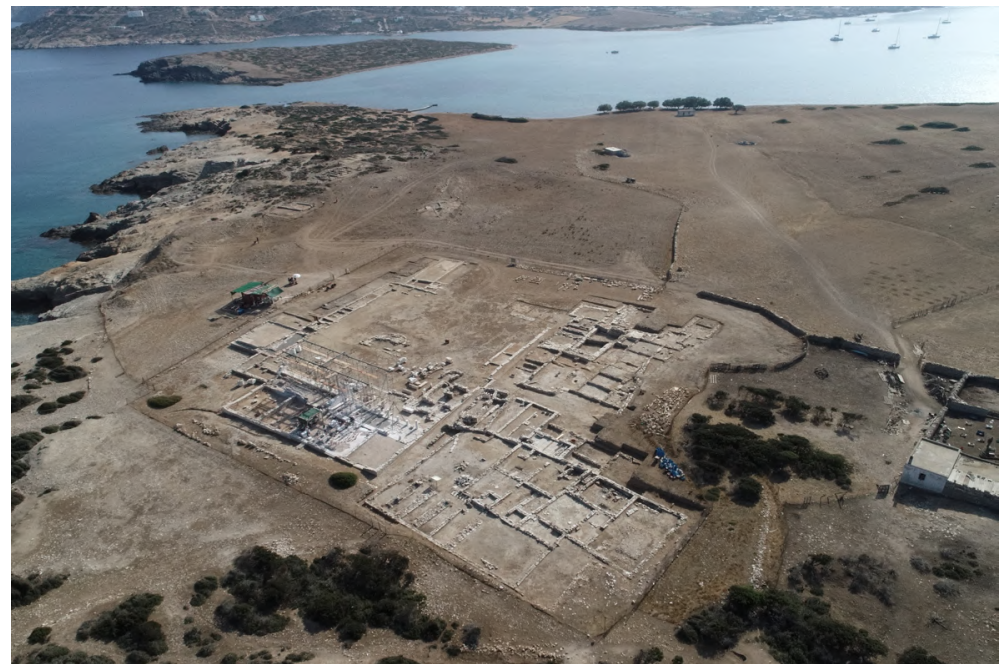

História: Questões \& Debates. Curitiba, v. 69, n. 1, p. 18-46, jan./jun. 2021. Universidade Federal do Paraná. ISSN: 0100-6932. DOI: http://dx.doi.org/10.5380/his.v00i0.000000 
Figura 6 - Cerâmicas com o nome de Apolo inscrito.

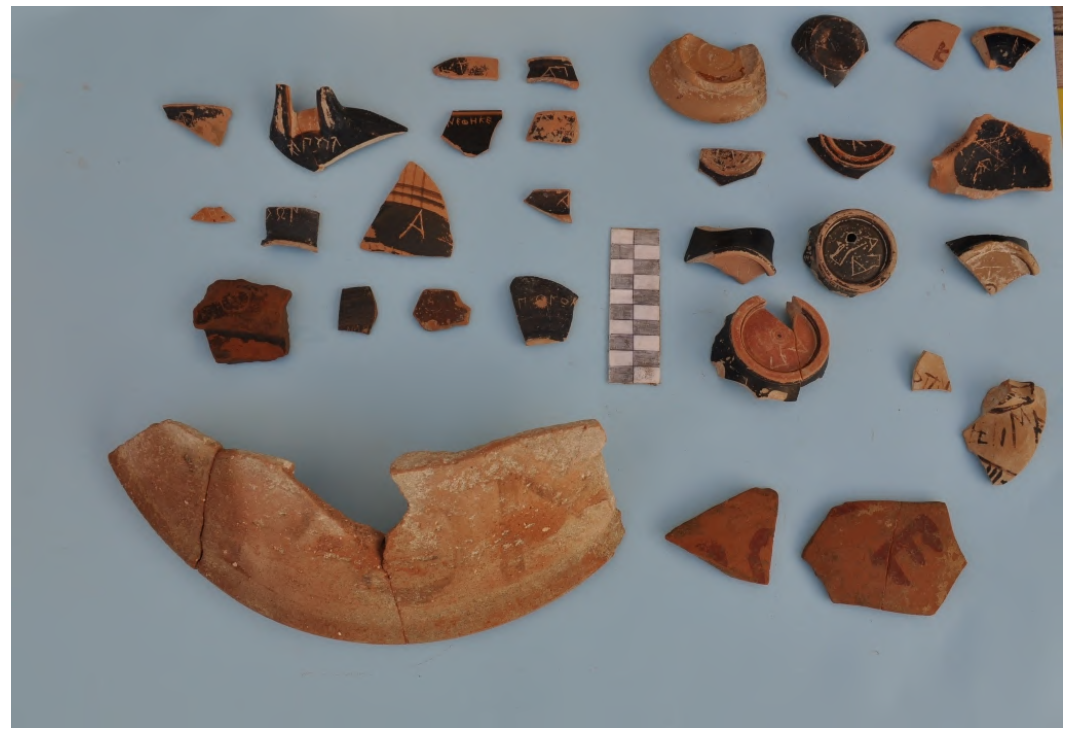

Figura 7 - Inscrição com o epíteto Isthimia.

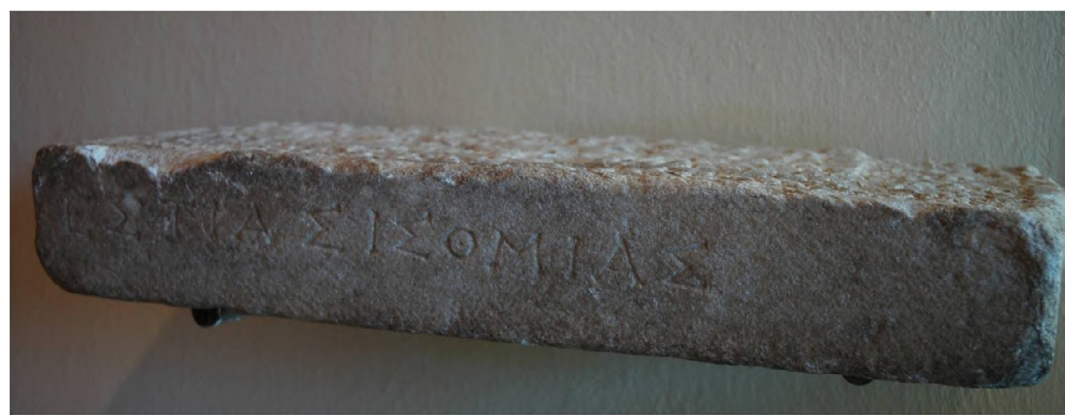


Figura 8 - Edifício arcaico $\Delta$ dentro qual foi encontrado uma estrutura apsidal.

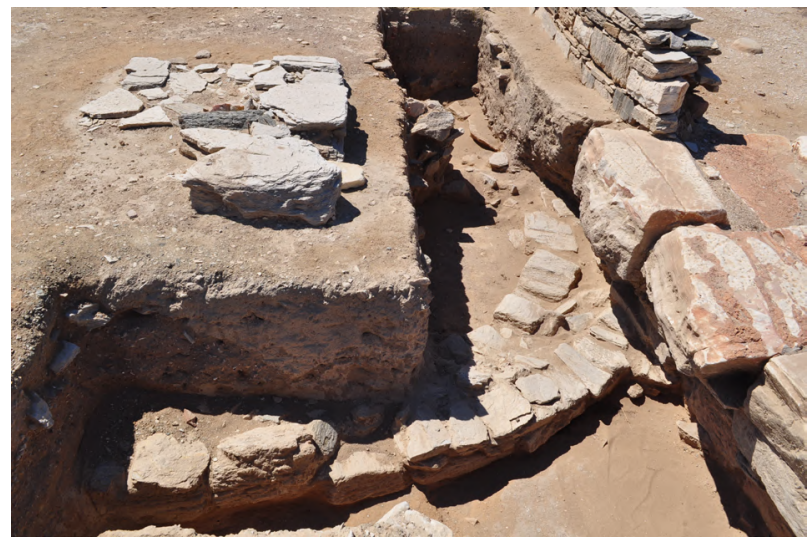

Figura 9 - Plano do edifício A com suas 3 fases de restauração de acordo com A. Ohnesorg e K. Papajanni (2009). Desenho feito por S. Papagrigoriou (2002).
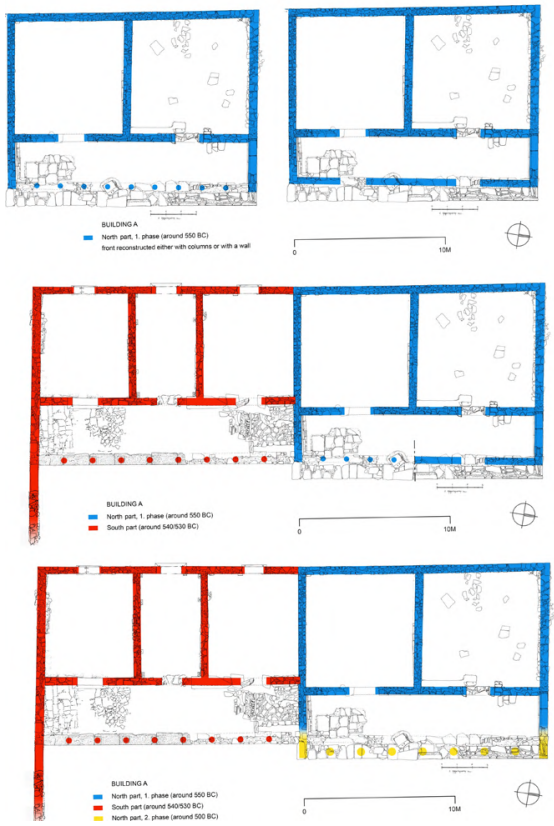

História: Questões \& Debates. Curitiba, v. 69, n. 1, p. 18-46, jan./jun. 2021. Universidade Federal do Paraná. ISSN: 0100-6932. DOI: http://dx.doi.org/10.5380/his.v00i0.000000 


\section{Figura 10 - Representação hipotética 3D do templo e estiatório e períbolos} (temenos norte) feita por G. Orestidis and S. Koulis (2012).

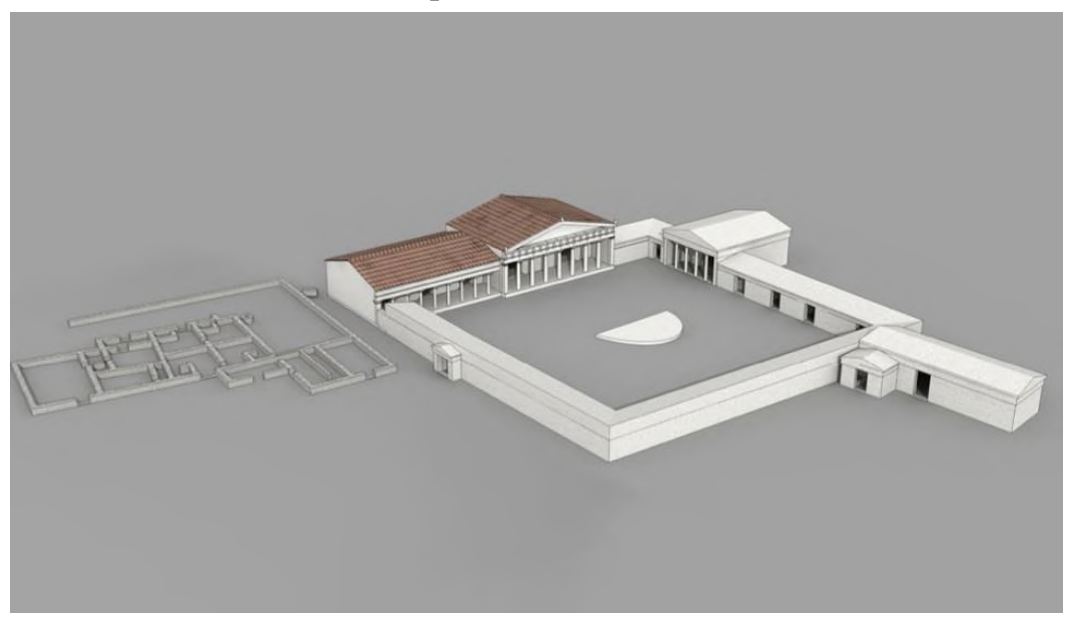

Figura 11 - Loutron.

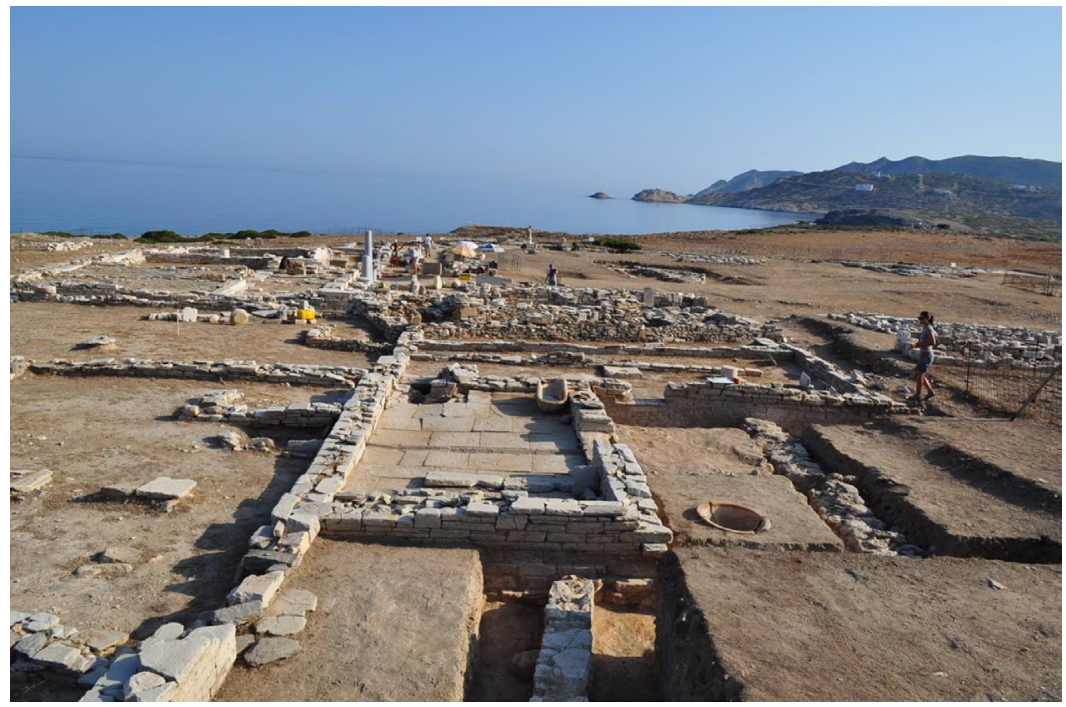




\section{Figuras 12, 13 e 14 - Estruturas arquitetônicas encontradas na ilha de Tsimintiri.}
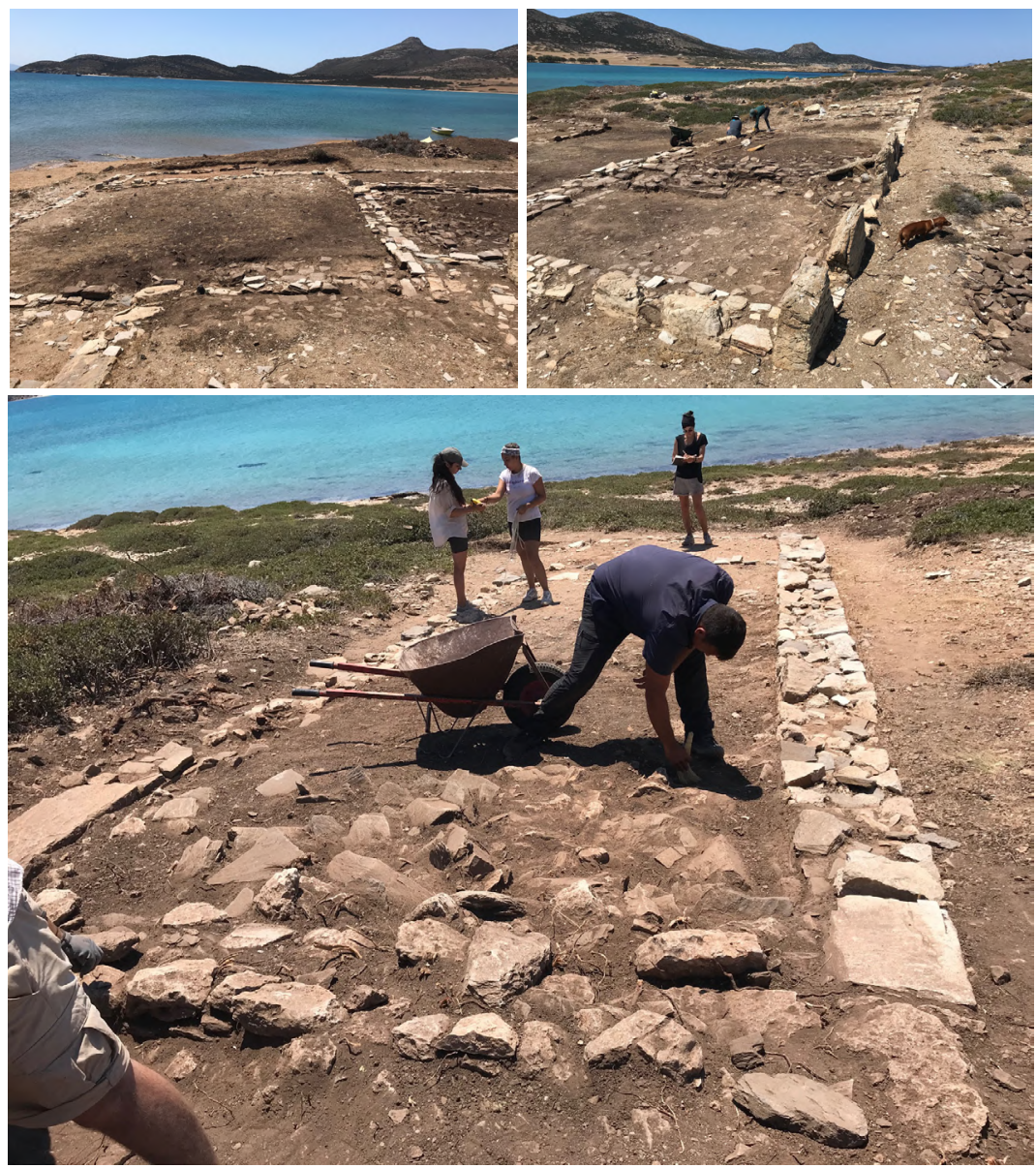
Figura 15 e 16 - Votivos encontrados no edifício A.
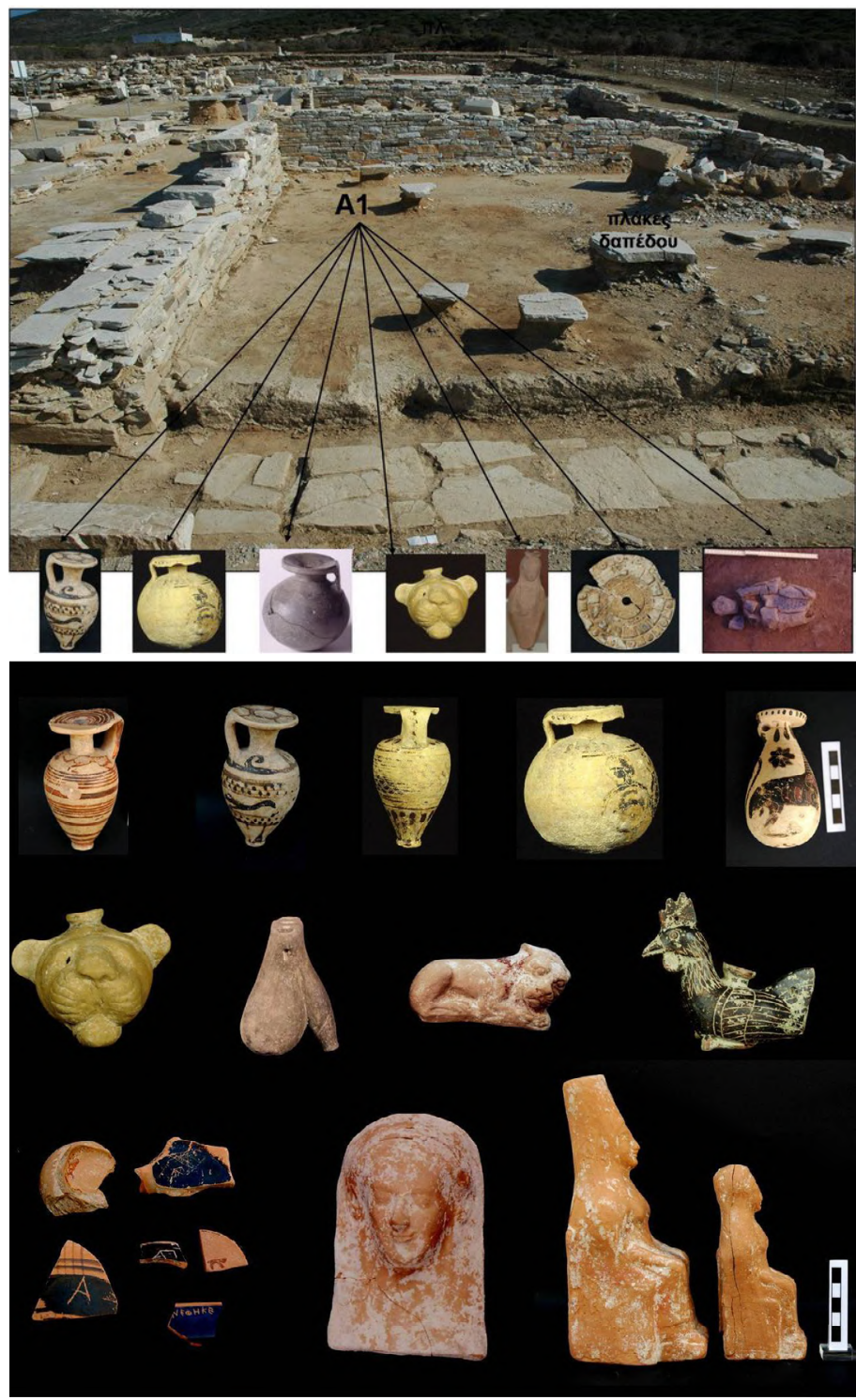

História: Questões \& Debates. Curitiba, v. 69, n. 1, p. 18-46, jan./jun. 2021. Universidade Federal do Paraná. ISSN: 0100-6932. DOI: http://dx.doi.org/10.5380/his.v00i0.000000 
Figura 17 - Selo encontrado no edifício A com cena de dança.

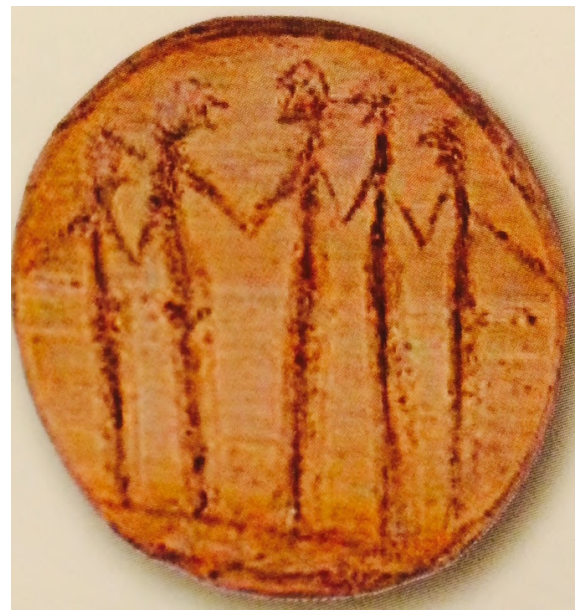

Figuras 18, 19, 20, 21 e 22 - Kouroi de Despótiko.

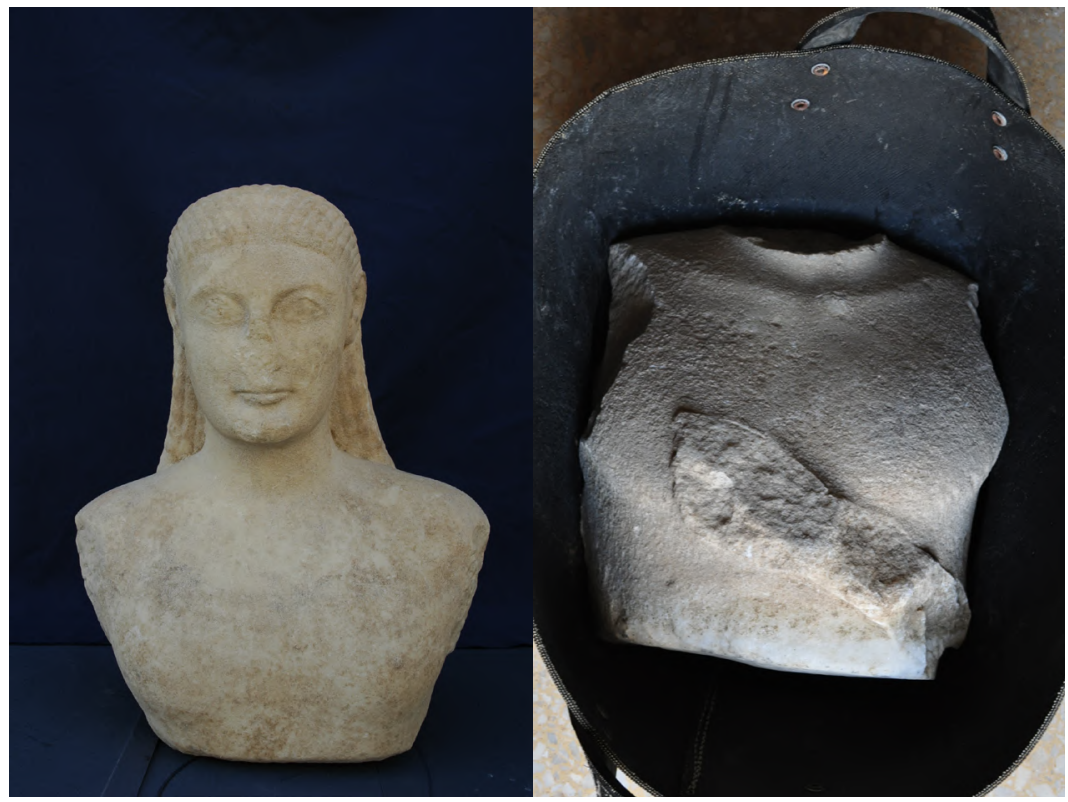

História: Questões \& Debates. Curitiba, v. 69, n. 1, p. 18-46, jan./jun. 2021. Universidade Federal do Paraná. ISSN: 0100-6932. DOI: http://dx.doi.org/10.5380/his.v00i0.000000 


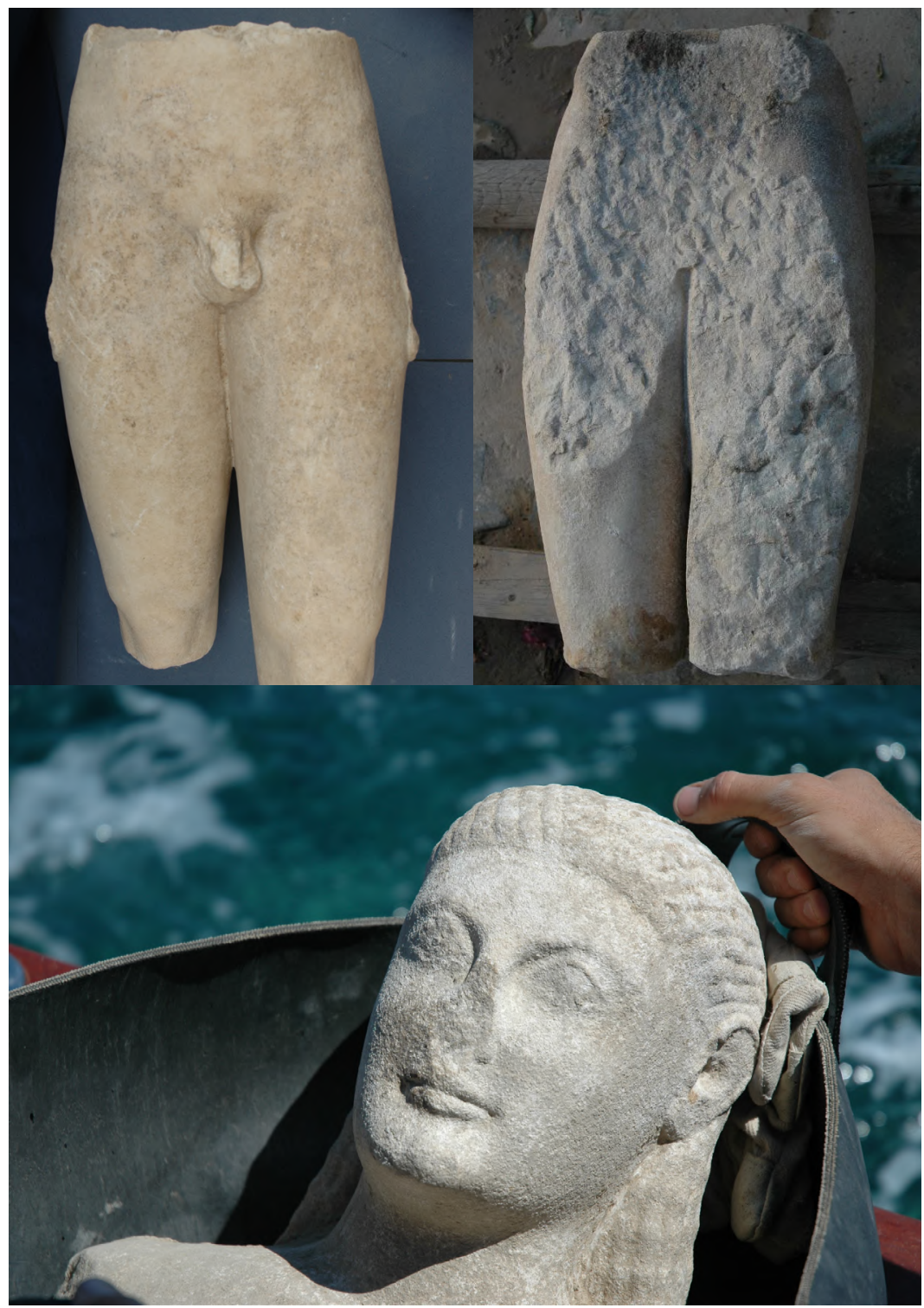

História: Questões \& Debates. Curitiba, v. 69, n. 1, p. 18-46, jan./jun. 2021. Universidade Federal do Paraná. ISSN: 0100-6932. DOI: http://dx.doi.org/10.5380/his.v00i0.000000 
Figuras 23 e 24 - Estátua arcaica em argila (estátua de culto, provavelmente representando Artêmis).

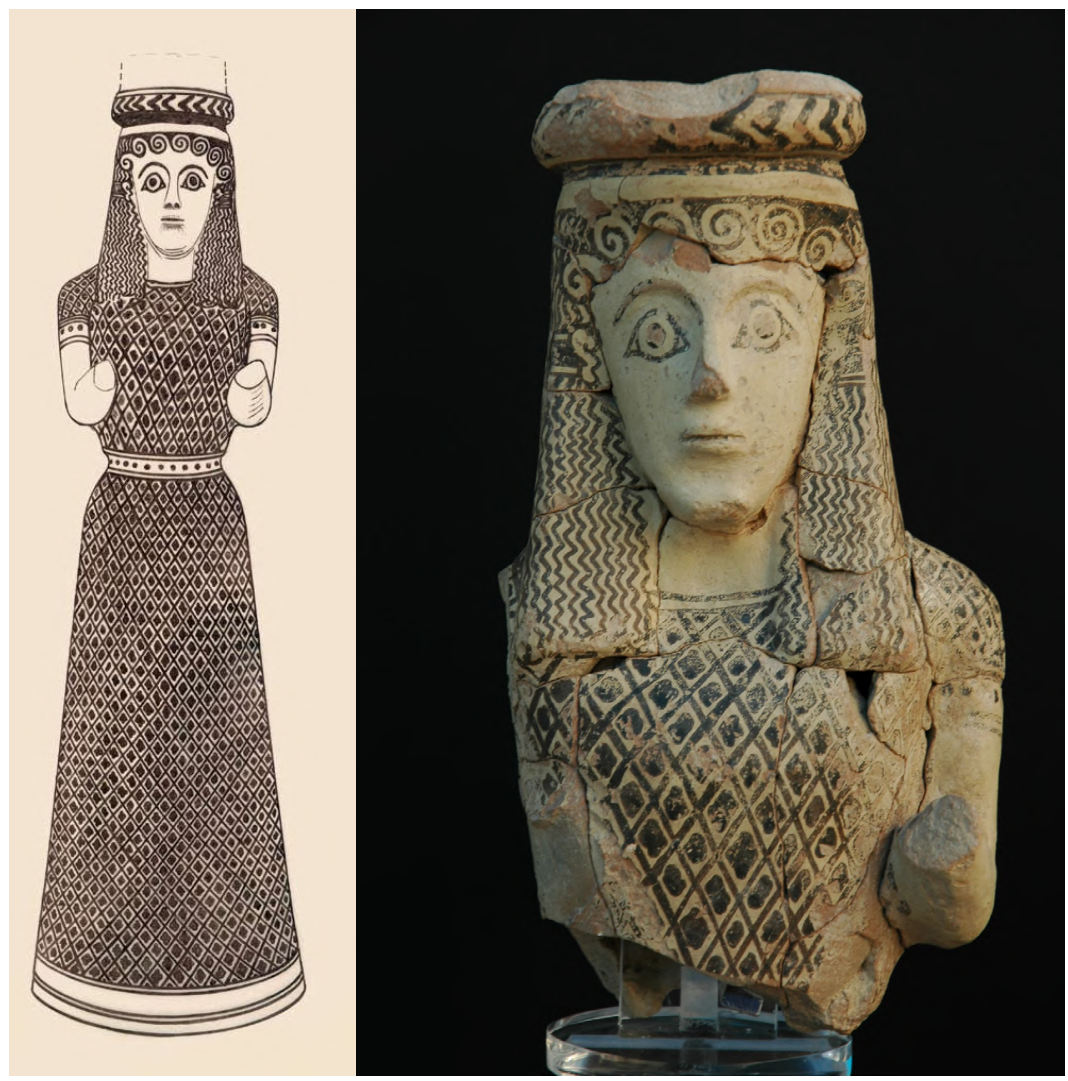


Figuras 25, 26, 27, 28, 29, 30 e 31 - Fotos da restauração do edifício A em Despótiko.
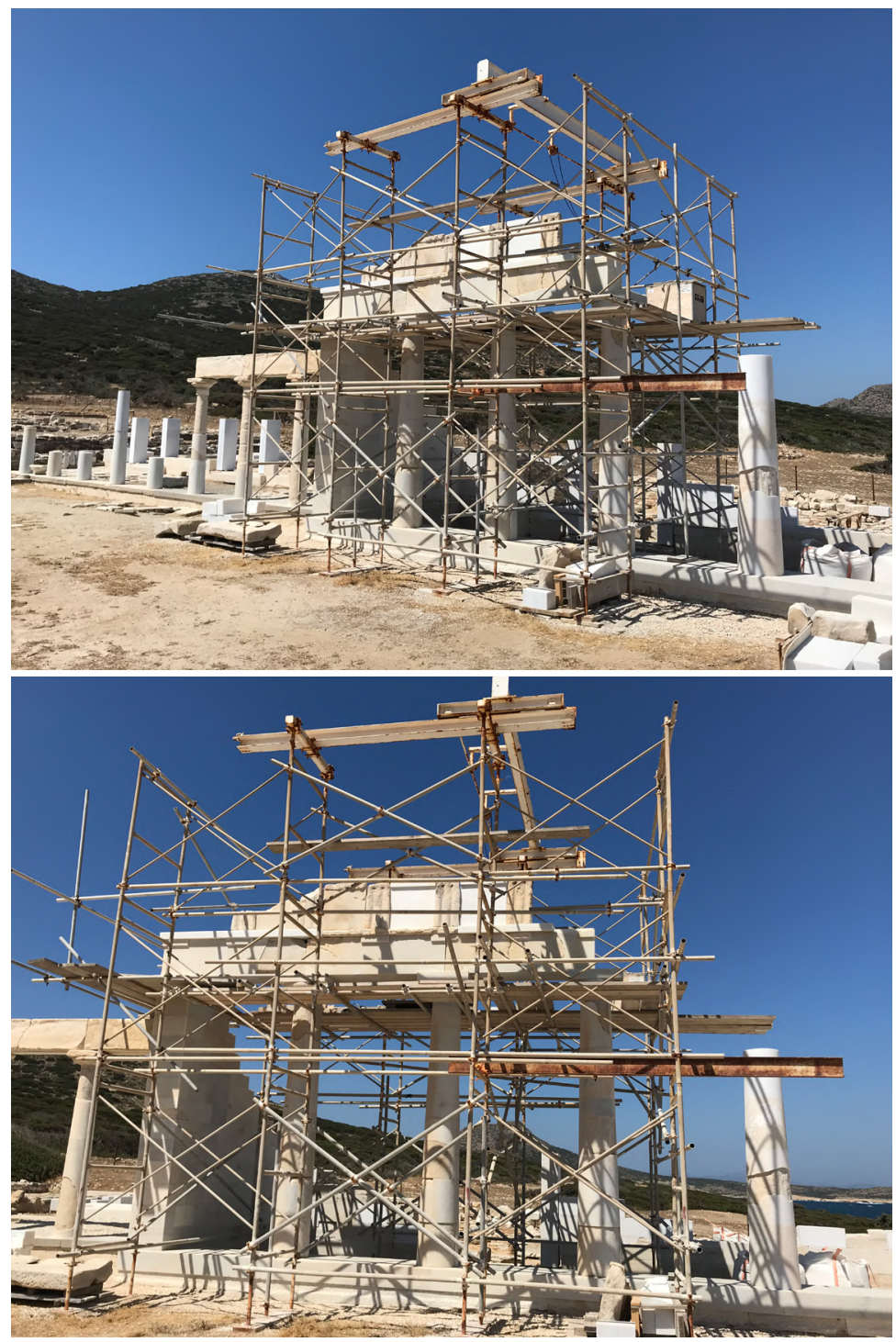

História: Questões \& Debates. Curitiba, v. 69, n. 1, p. 18-46, jan./jun. 2021. Universidade Federal do Paraná. ISSN: 0100-6932. DOI: http://dx.doi.org/10.5380/his.v00i0.000000 

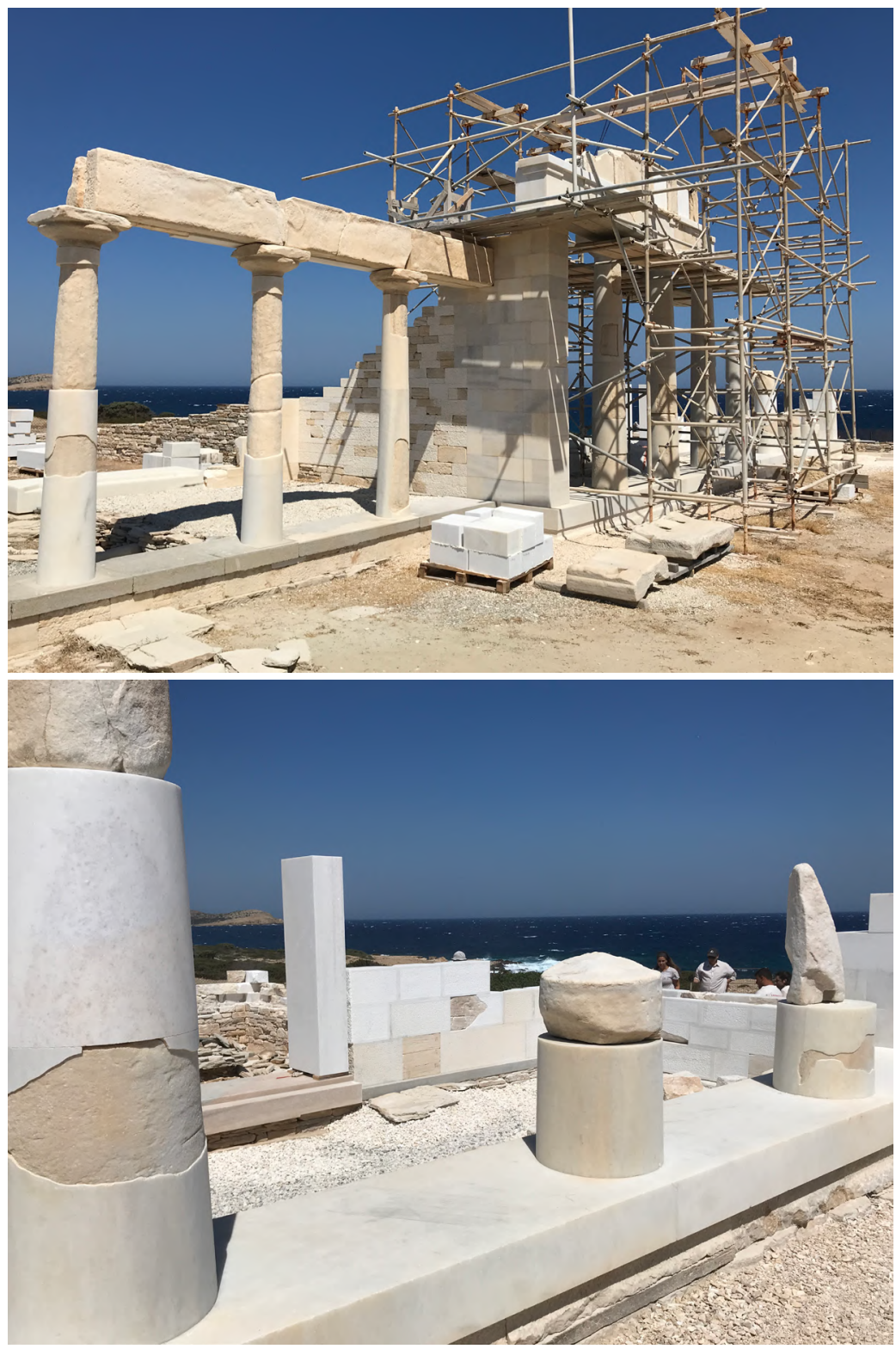

História: Questões \& Debates. Curitiba, v. 69, n. 1, p. 18-46, jan./jun. 2021. Universidade Federal do Paraná. ISSN: 0100-6932. DOI: http://dx.doi.org/10.5380/his.v00i0.000000 

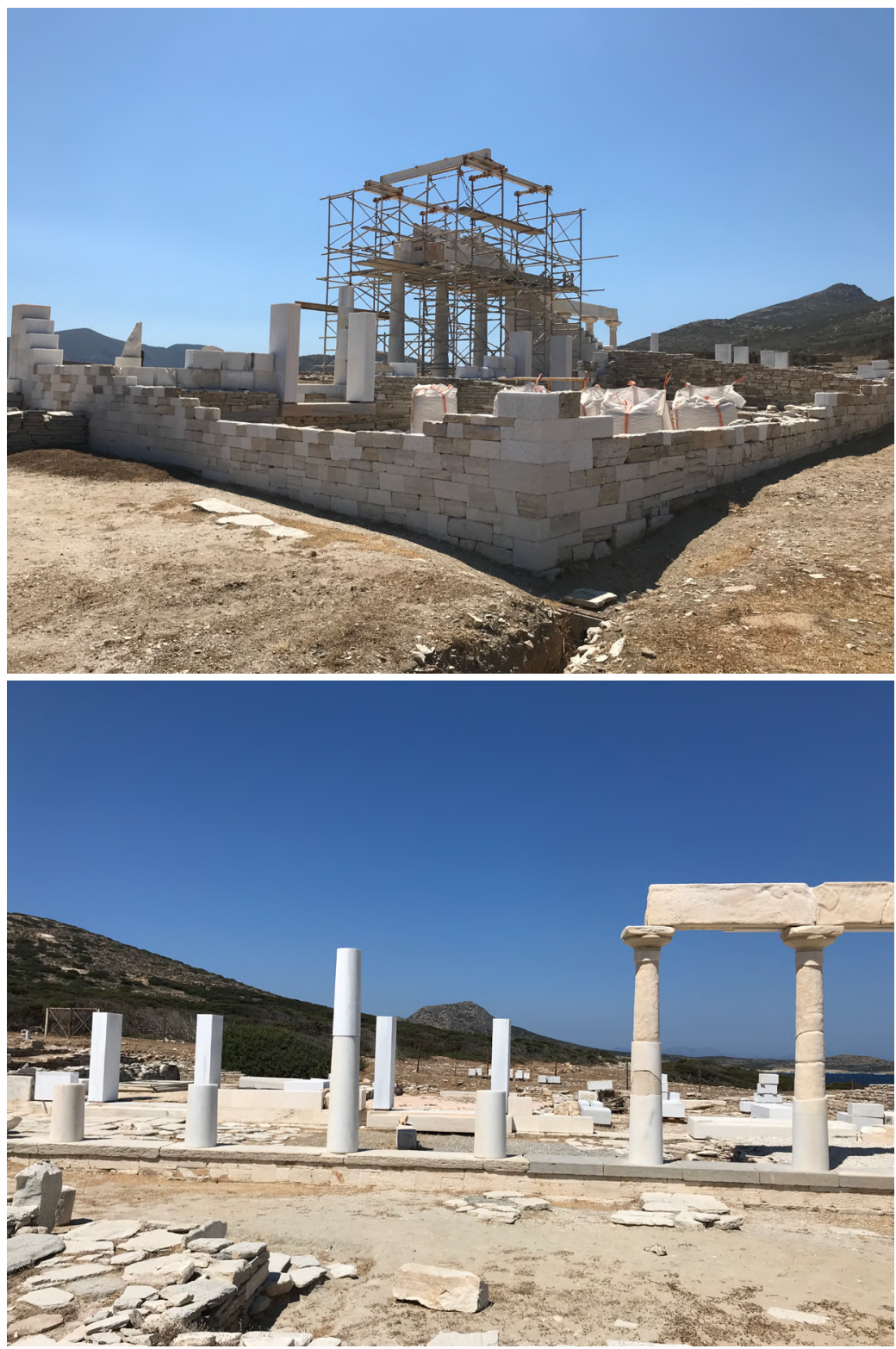

História: Questões \& Debates. Curitiba, v. 69, n. 1, p. 18-46, jan./jun. 2021. Universidade Federal do Paraná. ISSN: 0100-6932. DOI: http://dx.doi.org/10.5380/his.v00i0.000000 


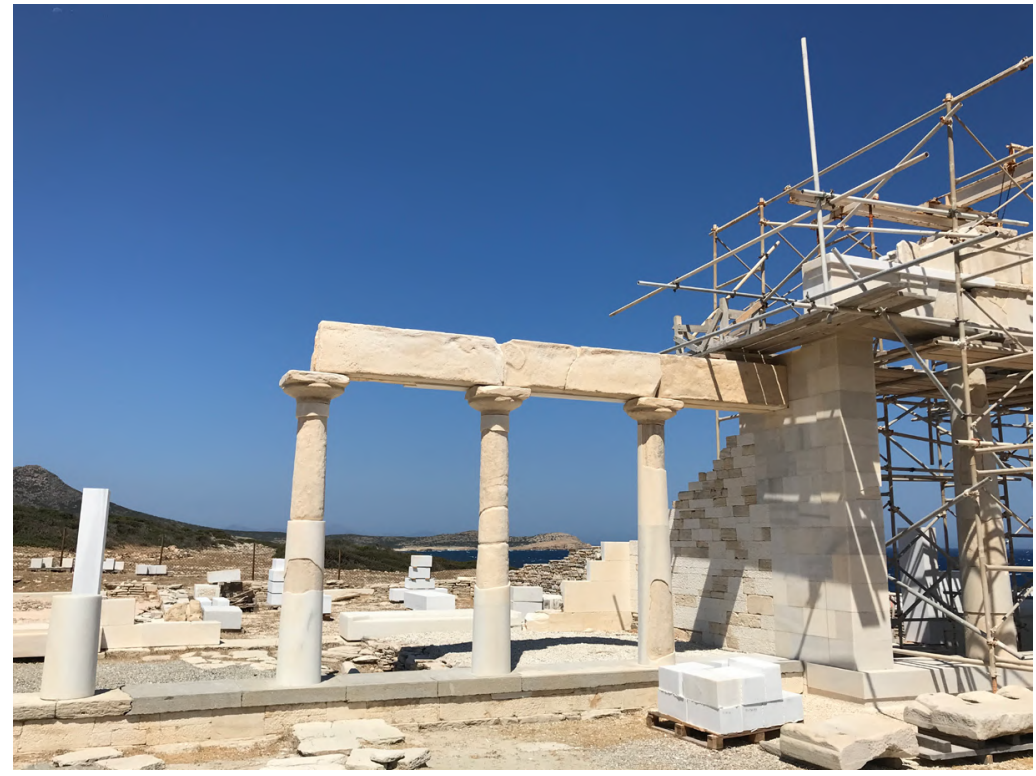

Referências bibliográficas

ALEXANDRIDOU, A. “"The Lady of Despotiko' Reconsidered: Cult Image or Cult Utensil?" In: E. Angliker and J. Tully (eds.). Cycladic Archaeology: New Approaches and Discoveries, Oxford: Archeopress, 2018, p. 87-100.

ALEXANDRIDOU, A. "Geometric Despotiko: On the Borderline Between Sacred and Profane". In: A. Tsingarida and I. Lemos (eds.). Beyond the Polis: Ritual Practices in Early Greece. Bruxelles: CReA-Patrimoin, 2019, p. 193-211.

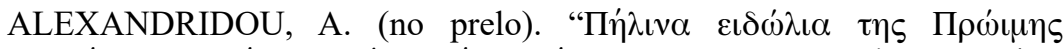

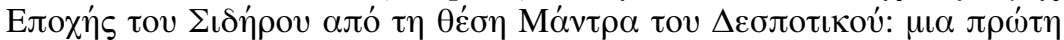

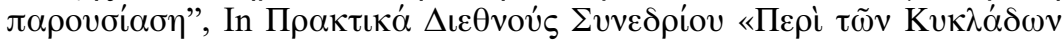

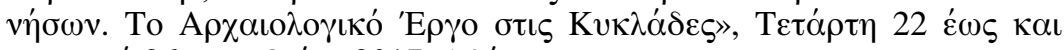

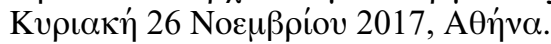




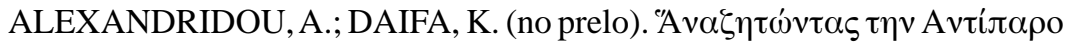

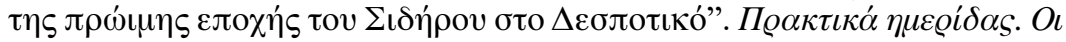

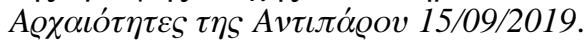

ANGLIKER, E. "The Treasuries of the Siphnians: Myth, Wealth and Decline Through the Exam of Archaeological Evidence." Phaos 14, 2014, p. 5-35.

ANGLIKER, E. "Worshiping Divinities at Archaic Sanctuaries in the Cyclades". In: A. Mazarakis-Ainian (ed.). Les Sanctuaries archaïques des Cyclades, Rennes: Press Université de Rennes, 2017, 29-53.

ANGLIKER, E. "Musical Instruments and Festivals of Apollo: A Study on the Auloi Dedications on the Sanctuary of Delos". In: A. Bellia and S. D. Bundrick (eds.). Musical Instruments as Votive Gifts in the Ancient World, («TELESTES. Studi e Ricerche di Archeologia musicale nel Mediterraneo», $I V)$, Pisa-Roma, Istituti Editoriali e Poligrafici Internazionali, 2019, p. 25-37.

BENT, J. H. The Cyclades or Life Among the Insular. London: Longmans, Green and co, 1885.

KOURAYOS, Y. "Despotiko Mandra. A sanctuary dedicated to Apollo". In: YEROULANOU, M.; STAMATOPOULOU, M. (eds.). Architecture and Archaeology in the Cyclades. Papers in Honour of J. J. Coulton. Oxford, Archaeopress, 1885, p. 105-133.

KOURAYOS, Y. “Fouilles du sanctuarie de Despotico, 2001-2003”. 2006. In: GRENIÈRE, J. (ed.). Les clients de la céramique grecque actes du colloque de l'Académie des Inscriptions et Belles-Lettres, Paris, 2006a, p. 30-31.

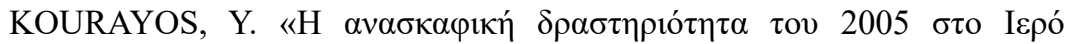

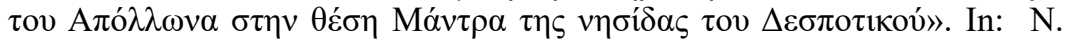

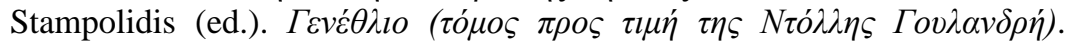
Cycladic Museum, Athens, 2006b, p. 147-158.

KOURAYOS, Y. Despotiko. The sanctuary of Apollo. Athens, P\&A Canellopoulos Foundation, 2012.

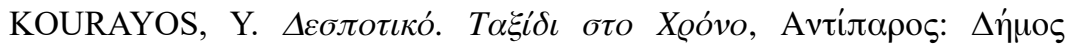

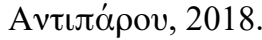

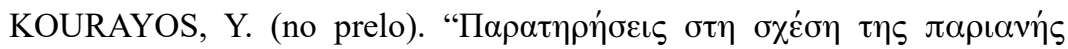

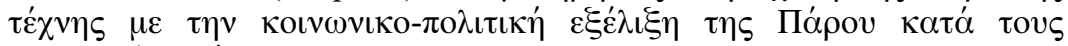

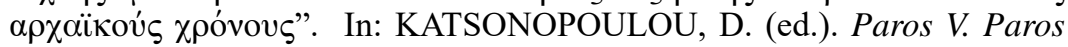
Through the Ages from Prehistoric Times to the $16^{\text {th }}$ Century AD. Athens: Ekdoseis Paragoges. 
KOURAYOS, Y.; ANGLIKER, E. (no prelo). "Figurines in Context: An Overview on the Figurines from the Sanctuary of Despotiko". In: KATSONOPOULOU, D. (ed.). Paros V. Paros Through the Ages from Prehistoric Times to the $16^{\text {th }}$ Century AD. Athens: Ekdoseis Paragoges.

KOURAYOS, Y.; OHNESORG, A.; PAPAJANNI, K. "The sanctuary of Despotiko in the Cyclades. Excavations 2001-2011". Archäologischer Anzeiger, 2, 2012, p. 93-176.

KOURAYOS, Y.; DAIFA, K. "Politics, Territory, and Religion in the Cycladic During the Archaic Period". In: MAZARAKIS-AINIAN, A. (ed.). Les Sanctuaries archaïques des Cyclades, Rennes: Press Université de Rennes, 2017, p. 307-134.

KOURAYOS, Y.; ALEXANDRIDOU, A.; PAPAJANNI, K.; DRAGANITS, E. "Ritual Dinning at thr Sanctuary of Apollo on Despotiko: The Evidence from Building $\Delta$ ". In: A. Mazarakis-Ainian (ed.). Les Sanctuaries archaïques des Cyclades. Rennes: Press Université de Rennes, 2017, p. 345-366.

KOURAYOS, Y.; BURNS, B. "Deposit of Small Findings from the Sanctuary of Apollo in the Island of Despotiko". In: A. Mazarakis-Ainian (ed.). Les Sanctuaries archaïques des Cyclades .Rennes: Press Université de Rennes, 2017, p. 327-344.

KOURAYOS, Y.; ANGLIKER, E.; DAIFA, K.; TULLY, J. "The Cult Topography of Paros from $9^{\text {th }}$ to $4^{\text {th }}$ century BC: A Summary" In: ANGLIKER, E.; TULLY, J. (eds.). Cycladic Archaeology: New Approaches and Discoveries, Oxford: Archeopress, 2018, p. 135-165.

KOURAYOS, Y.; SUTTON, R.; DAIFA, K. "Miltiades on Paros: New Evidence from Despotiko" In: ANGLIKER, E.; TULLY, J. (eds.). Cycladic Archaeology: New Approaches and Discoveries, Oxford: Archeopress, 2018, 113-5-165.

KOURAYOS, Y.; DAIFA, K.; ORESTIDIS, G.; EGGLEZOZ, D.; PAPAVASILEIOU, V.; TOUMBAKARI, E.E. "The Temple Hestiatorion of the Danctuary on Despotiko: Archaeology, Architectury, and Restoration". In: P. Sapirstein and D. Scahill (eds.). New Directions and Paradigms for the Study of Greek Architecture. Interdisciplinary Dialogues in the Field. Leiden, Brill, 2020, p. 135-150. 


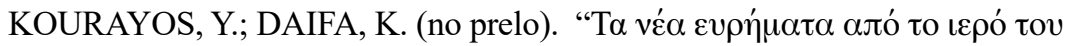

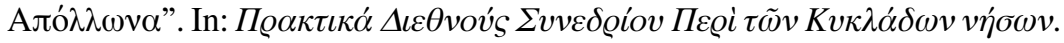

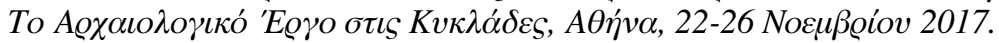

KOURAYOS, Y.; SUTTON, R.; HASAKI, E. E. (no prelo a). The Temple of Despotiko and its deposits. Babesch Supplement.

KOURAYOS, Y.; ALEXANDRIDOU, A.; DAIFA, K. (no prelo b).

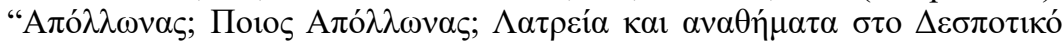

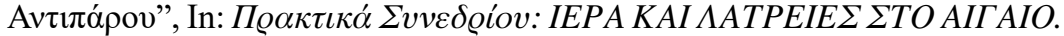

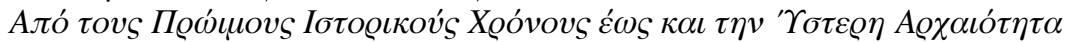

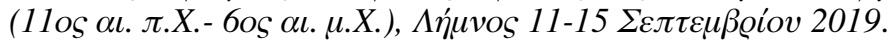

OHNESORG, A. "Island-Ionic and Island-Doric Architecture on the Cyclades. An Overview". In: Les Sanctuaries archaïques des Cyclades A. Mazarakis-Ainian (ed.). Rennes: Press Université de Rennes, 2017, p. 55-72.

POLIGNAC, F. de. Cults, Territory and the Origins of the Greek City-State. Translated by J. Lloyd. Chicago: The University of Chicago Press, 1995a.

SCHULLER, M. "Die dorische Architektur der Kykladen in spätarchaischer Zeit." Jahrbuch des Deutschen Archäologischen Instituts 100, 1985, p. 319-398.

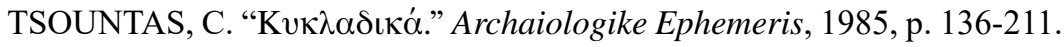

RECEBIDO EM: 04/09/2020 APROVADO EM: 17/09/2020 